\title{
Gender, Sexuality, and the State in Southeast Asia
}

\section{MICHAEL G. PELETZ}

$\mathrm{M}$

Y COMMENTS IN THIS essay focus on recent scholarship on gender, sexuality, and the state in Southeast Asia and include brief remarks on some of the literature regarding Southeast Asians in the diaspora. In the interests of transparency, I begin by noting that I am an anthropologist by trade and that many of my observations pertain to writings by anthropologists and historians, though I also engage work in other disciplines. ${ }^{1}$

One of my central concerns is to delineate common trends and other patterns in the relevant scholarship bearing on Southeast Asia, patterns that point to both similarities and differences vis-à-vis gendered dynamics in other, less politically fissiparous parts of Asia. I argue that certain of these patterns reflect divisions of labor between anthropologists and historians; others the stubborn persistence of a Marxist-oriented "political economy” versus Weberian/Geertzian-inflected "interpretive/symbolic/cultural" dichotomy in anthropology and kindred fields; still others the ways that regional and religious variation articulates with underlying commonalities in this vibrant, complex world area. Related themes have to do with scholarly emphases on gendered and sexual violence by the state; women's activism; and the sexual/gender politics of moral policing and what I refer to as graduated pluralism. In my concluding remarks, I provide synoptic observations on two other tendencies in the literature: the relative neglect of heteronormative masculinities and scholars' generally negative views of the state.

\section{Divisions of Labor, Disciplinary Conundrums, Graduated Sovereignty}

Many of us who deal with topics that are the subject of this essay are deeply indebted to historian Barbara Andaya. I am thinking most immediately of her

\footnotetext{
Michael G. Peletz (mpeletz@emory.edu) is Professor of Anthropology at Emory University. ${ }^{1}$ I should perhaps clarify two additional points, as well. First, I take as my point of departure literature attending closely to gender and/or sexuality (portions of which deal substantively if at times indirectly with the state), rather than writing prioritizing the state (much of which ignores gender and sexuality altogether). A different point of departure would have resulted in a (very) different essay. And second, this essay deals primarily with lowland areas of Southeast Asia and is perhaps disproportionately oriented toward large urban settings (Bangkok, Ho Chi Minh City, Rangoon, etc.) that have increasingly served as the contexts for anthropological and other scholarly writing on the region (and its diaspora). Limitations of space preclude consideration of highland locales such as those in Zomia (Scott 2009).
} 
2006 volume, The Flaming Womb, which aims to reposition women in Southeast Asia during the early modern period, roughly the fifteenth to the eighteenth centuries. This book brings so much to the table that I can only list a few of its virtues in passing. They include Andaya's extensive engagement with complex issues of historiography; her discussion of the conundrums of writing "women's history"; and her detailed exegesis on the heuristic value and pitfalls of the concept of "Southeast Asia," which she addresses partly through an innovative investigation of women and gender in border zones and neighboring regions, including southern China, Taiwan, Vietnam, Bengal, Assam, Manipur, Arakan, Sri Lanka, and Oceania. Worthy of mention as well is her nuanced and sophisticated treatment of the ways women of different social classes engaged the momentous political, economic, and religious changes that occurred during this crucial period in Southeast Asia's history. Andaya also provides incisive commentary on sexual and gender ambiguities associated with anatomical intersexuality and cross-dressing, though she does not deal substantively with issues bearing on transgender practices or same-sex relations. ${ }^{3}$

${ }^{2}$ The term "Southeast Asia" is currently used by different scholars in different ways. Certain scholars utilize it to index a series of overlapping "culture areas" (Austronesian, Indic, or other) presumed to share an important range of commonalities (in kinship, gender, and religion, for example) whose boundaries diverge significantly from "Southeast Asia" as a geopolitical region (which is usually held to consist of eleven nation-states: Vietnam, Cambodia, Laos, Thailand, Burma [Myanmar], Malaysia, Singapore, Brunei, Indonesia, East Timor [Timor-Leste], and the Philippines). Others deploy the term to designate a "world area" characterized by underlying similarities with respect to its positioning on the world stage, particularly in relation to global circuits of capital, labor, technology, and the like, whose salience is viewed as superseding commonalities defined in more traditional "cultural" terms. More generally, while debates concerning the viability of the designation "Southeast Asia" and its geopolitical, spatial, and cultural referents continue to engage historians, anthropologists, and others, there is little disagreement that movement, hybridity, porousness, and pluralism have long been prominent features of the region, however broadly or narrowly defined (Day 2002, 291-93 passim). This is strikingly evident when we transcend the relevant national contexts, which serve as the usual frames of scholarly writing on this region of Asia, and incorporate perspectives drawn from diasporic settings such as Japan, Hong Kong, the Middle East, and the United States into our analyses. From an analytic point of view, a good many of the cultural practices, identities, and subjectivities forged in these latter contexts are as legitimately Southeast Asian as those encompassed within more conventional studies of the region. Partly for this reason, my discussion of recent scholarship on Southeast Asia includes brief consideration of literature on Southeast Asians in the diaspora.

${ }^{3}$ For my purposes, the term "gender" designates the cultural categories, symbols, meanings, practices, and institutionalized arrangements bearing on at least five sets of phenomena: (1) females and femininity; (2) males and masculinity; (3) androgynes, who are partly male and partly female in appearance, as well as intersexed individuals, who to one or another degree may have both male and female sexual organs or characteristics; (4) the transgendered, who engage in practices that transcend or transgress normative boundaries and are thus by definition "transgressively gendered"; and (5) neutered or unsexed/ungendered individuals, like some eunuchs. "Sex," by contrast, refers to physical activities associated with desire, reproduction, and the like, including but not limited to sexual intercourse of a heterosexual nature; to physical bodies that are distinguished by having genitals that are construed as "female," "male," both (as with some intersexuals), or neither (as in the case of some eunuchs); and to bodily processes associated with anatomical and physiological 
The latter comment is not intended as a critique. I mention it because it indexes a disciplinary division of labor in the region. Historians and others (e.g., Stoler 1995, 2002) who deal primarily with archival records bearing on gender and sexuality in Southeast Asia tend to concentrate on heteronormativity. Anthropologists of Southeast Asia, by contrast, particularly if they engage in ethnographic research (as most do), commonly focus on non-normative genders and sexualities or at least are more inclined than historians and others to do so. This is readily apparent when one considers the importance of ethnographic material and theoretical interventions from Evelyn Blackwood (2010), Tom Boellstorff (2005, 2007), Sharyn Davies (2010), Peter Jackson (1997), Mark Johnson (1997), Martin Manalansan (2003), Rosalind Morris (1994), Dede Oetomo (1996), Megan Sinnott (2004), and Saskia Wieringa (1999, 2010; cf. Blackwood and Wieringa 1999; Wieringa, Blackwood, and Bhaiya 2007). There are obvious methodological and other reasons for these patterns, some of which have to do with the kinds of written records, voices, and other data that different communities of scholars are privy to-and equally obvious exceptions to the rule. Historian Tamara Loos’s (2005) work on political culture, sexuality, and law in Siam during the reign of King Chulalongkorn (1868-1910) comes immediately to mind as one such exception (see also Loos 2009).

Gyanendra Pandey (2006, 31-32) has observed that, owing to the nature of the written sources available to historians of South Asia, it is much easier to document the broad contours of political, economic, and religious change than to provide nuanced accounts of the lived experiences and subjectivities of variously defined groups of subalterns and their transformations through time. This is also true of Southeast Asia (and most of the rest of the world). Historians dealing with gender and sexuality in Southeast Asia are understandably more concerned with macro-level changes instigated by or associated with state actors and their policies, which are in many ways much easier to discern in hindsight, than they are with affect, subjectivity, and experience, which are often inaccessible via the archival record. Anthropologists face different challenges, especially if they and those they engage in the field are living through temporal changes whose multiple directionalities and oftentimes paradoxical outcomes are not yet obvious, which is typically the case.

Other conundrums facing anthropologists and others who write mostly about the present have to do with the fact that contemporary states are widely viewed as multi-headed hydras and (for reasons sketched out by social theorist Philip Abrams [1988]; see also Mitchell [1991], Day [2002], and Aretxaga [2003]) are notoriously difficult to study. ${ }^{4}$ There is a related dynamic that has also

maturation, such as menstruation and ejaculation. The partially overlapping term "sexuality" bears more specifically on the realm of erotic desire, fantasy, passion, and pleasure.

${ }^{4}$ Some of the difficulties: What exactly is the state? How and where do we locate the boundaries between state and society? How do we distinguish between the ideology of a state with respect to the state's essence, cohesion, unification, operation, etc. (the "state-idea"), on the one hand, 
encouraged anthropologists and others to approach the study of present-day states orthogonally: In the past few decades, states throughout Southeast Asia have increasingly delegated projects of governance to market forces, transnational corporations, and the techno-bureaucratic management and auditing regimes associated with them. These processes of outsourcing and privatization are part and parcel of neoliberal globalization, commonly associated with the post-1970s era, as defined by David Harvey (2005), Jean and John Comaroff (2000), Aihwa Ong (1999, 2006), Lisa Rofel (2007), and their interlocutors. Before elaborating on some of the relevant issues, it is well to bear in mind an observation made by James Scott (1985) about Malay peasants in Kedah in the early 1980s. Scott's point is that they do not experience class warfare or the creeping cash nexus in the abstract. Rather, they typically experience these and attendant phenomena in very concrete ways: in terms of a subtle (or not-so-subtle) ratcheting up of demands on their labor power, along with a gradual (or abrupt) contraction of material or symbolic reciprocities on the part of patrons or others with political clout. These insights are germane to our understanding of how neoliberalism informs gender and sexual dynamics in Southeast Asia, and how far-reaching but invariably uneven global processes are experienced in intimate and embodied ways by variably situated social actors on the ground.

Anthropologist Ara Wilson's The Intimate Economies of Bangkok (2004) provides a good illustration of some of these themes, addressing how modernization, transnational capitalism, and globalization affect women's everyday lives and subjectivities. Responding to Gayle Rubin's (1984) call for a robust "political economy of sex," Wilson builds on Aihwa Ong's concept of graduated sovereignty, which emphasizes "how the state makes different kinds of biopolitical investments in different subject populations" (Ong 1999, 217), and engages in multi-sited research that examines women's involvement in contrasting forms of market activity. These include department stores, the sex trade, downtown megamalls, and Amway and Avon direct sales. Each form of economic activity has site-specific entailments with respect to gender and/or sexuality, and each in its own way expands the frontiers of commodity exchange, albeit incompletely and typically in contradictory fashion, into "further reaches of social life" (Wilson 2004, 68). Wilson writes that "the public concern with sex workers as a blight on the nation's image, or as social disorder, codes a more inchoate criticism of the rapid commodification of the ... economies and lives" of Thai citizens from all walks of life (99). More generally, the heightened visibility of gay men, toms (short for tomboys; masculine women involved in same-sex relations with other women), and kathoey (feminized phenotypic males) in shopping malls symbolizes

and the empirical political realities of these phenomena (the "state-system") on the other? How do we connect both the state-idea and the state-system to other modalities of power and governance (Abrams 1988, 82)? 
the twin excesses of state-sponsored capitalist development and transnational consumer culture in an environment where Thais are increasingly spending "more on 'recreation and entertainment' ... than on clothes and rent" (109). Put differently, materialist youth, gender benders, and mercenary sex workers emerge in nationalist discourses as symbols and targets of the malaise (180). The real culprit, however, is the largely illegible, unholy alliance involving transnational capital, state policies, and the political and economic elites in Thailand and elsewhere who reap enormous profits from Thai-style development.

Analogous dynamics are evident elsewhere. The case of Vietnam is incisively documented by political scientist Nguyen-vo Thu-Huong in her 2008 book, The Ironies of Freedom, which focuses on sex, culture, and neoliberal governance in Ho Chi Minh City since the Doi Moi reforms of the late 1980s. Nguyenvo describes her project as a case study of how Vietnam's former socialist government is adapting to the market and its neoliberal discourses on freedom and choice. A key strategy centers on graduated sovereignty: promoting policies that entail freedom to choose for certain sectors of the population involved in state-sanctioned entrepreneurial activities and modes of consumption, while simultaneously denying such freedom to other sectors of the population, some of which are targeted for harsh repression (xxii). The commercialization of various state units since the mid-1980s, for instance, has turned most bureaucrats into state entrepreneurs, two-thirds of whom routinely purchase the sexual favors of Vietnamese women to help them close business deals (23). Thus, even though public health campaigns depict sex workers as agents of deadly disease, moral turpitude, and social evil, and commonly insist on their incarceration and "rehabilitation," prostitution is both "integral to the marketization of the Vietnamese economy" and vital for the affirmation of a newly ascendant Vietnamese masculinity $(24,25)$. Class-oriented notions of femininity are of course centrally implicated as well. One reason for this is that women of the burgeoning, urban middle class are in some ways defined in sharp opposition to sex workers, many of whom hail from impoverished, rural backgrounds. This despite the fact that they are also encouraged to accept the view that, as Nguyen-vo puts it, "middle-class wifeliness" involves outperforming "prostitutes and doing it all within the hygienic confines of the conjugal bed" (113).

A related theme is that national debates have increasingly concerned the defining features of post-socialist Vietnameseness. To quote Nguyen-vo once again, "If 'Vietnam is a country, not a war', as the saying goes," then what defines the nation is very much "up for grabs" (43). Equally obvious is that much of the grabbing is directed toward women's bodies and reproductive

${ }^{5}$ I italicize terms such as "gay" when I seek to emphasize one or another Asian identity or Asianlanguage usage. I use a regular font when deploying the terms to convey their now conventional English-language meanings (e.g., a person inclined toward erotic relations with others of the same sex). 
activities, along with their mannerisms, pastimes, and presence in public spaces $(45,48)$.

In this context, it is worth emphasizing that rates of abortion in Vietnam are among the highest in the world, with some studies indicating as many as 1,700 abortions per 1,000 live births when the rates peaked in the mid- to late 1990s (Bich 1999, 193). Most Vietnamese women who seek to terminate their pregnancies are married, have two or more children, and are between 25 and 40 years old (though teenage girls represent a rapidly increasing percentage of the total). Data bearing primarily on women in this age group indicate that in 1992 the "total abortion rate for the country was at least 2.5 per woman" (Bich 1999, 194; Croll 2000, 48), a figure that by 2002 may have declined to around 1.1 per woman. ${ }^{6}$ The government's one- or two-child family policy along with cultural preferences for sons contribute to the prevalence of abortion, but many other factors are involved. Foremost among these are state policies downplaying sex education in schools, which result in a lack of reliable information among curious, sexually active youth; the difficulty, especially in rural areas, of purchasing condoms (another state effect); and the widespread reliance on intrauterine devices (IUDs), which are ultimately less efficacious than condoms, but are nonetheless promoted by the state, to prevent conception. In short, largely because of state policies, IUDs are commonplace (but not as extensively used as they might be), and so too are abortions. It remains to add that IUDs are ineffective in preventing the spread of sexually transmitted diseases such as HIV/AIDS; that partly for this reason Vietnam is now confronting an alarming epidemic of HIV/AIDS; that the epidemic is spreading to the general population though it is currently concentrated among sex workers, their clients, and their clients' regular partners on the one hand, and among intravenous drug users and their partners on the other; and that state policies are directly implicated in high rates of abortion and HIV/AIDS alike.

\section{Gendered and Sexual Violence by the State}

Recent scholarship on gender and sexuality in Burma (Myanmar) has a somewhat different flavor than the research I have surveyed thus far. This is mostly because of the extremely repressive policies that Burmese leaders have pursued since the early 1960s. Anthropologist Monique Skidmore's Karaoke Fascism (2004), a fine study of how women and men in Rangoon experience state-sponsored violence and terror, is relevant here. Skidmore emphasizes that for the residents of Rangoon, violence is a salient dimension of everyday life, not simply a technique of intimidation, retaliation, or control that authorities

\footnotetext{
${ }^{6}$ This according to data released in 2003 and updated in 2004 by Hanoi's General Statistical Office (Ipas 2004). More recent data do not seem all that reliable.
} 
trot out when necessary. Building on the contributions of Veena Das, Paul Farmer, and Michael Taussig, she distinguishes three different modalities of violence: direct violence, such as physical torture by state agents; indirect violence, involving the perpetration of fear, terror, surveillance, rumor, and suspicion; and structural violence of the sort that marginalizes entire groups of people, seriously diminishing their basic life chances (160). Skidmore provides superb if deeply disturbing documentation of the cognitive, affective, and behavioral strategies deployed by women (and to a lesser extent men) to try to come to terms with the violence and uncertainties of everyday life, indicating (among other things) that as many as one-third of all women of reproductive age in Rangoon's periurban townships are involved in deeply alienating prostitution to make ends meet (162). She also explores some of the ethical questions involved in this kind of research, which commonly calls for engaging interlocutors in the field with questions that evoke painful memories of violence and trauma. In this respect (and others), Skidmore's work complements scholarship on South Asia (Butalia 2000; Das 1995) that explores some of the more intimate and disturbing aspects of the struggles and violence associated with the post-war partition of India.

Here we might reflect briefly on how quickly things appear to be changing in Burma. Consider the photos of smiling member of Parliament Aung San Suu Kyi travelling freely about the countryside that have appeared in The New York Times and The Economist since early 2012, which are also widely circulated via digital media. This is the same remarkable woman who, a mere two years ago, had been detained by the junta for the better part of twenty years. During that time, Aung San Suu Kyi was demonized by the junta's Orwellian propaganda machines in explicitly gendered and sexualized terms. Key elements of this strategy involved the construction and dissemination of narratives spun around the fact that Aung San Suu Kyi is a woman and that, like all women, she uses female guile and manipulation to achieve her divisive goals, including leadership of the National League for Democracy (the major opposition party). Like all other women, she was also said to be driven by lust and was portrayed as otherwise unfit for an office that involves leadership of the country and stewardship of its cultural patrimony and other resources. Her long-term marriage to a Briton (Michael Aris, who died in 1999) and her two "mixed-race" children added to her sins and deficiencies as far as the xenophobic junta was concerned. The generals also portrayed Aung San Suu Kyi as wild and uncivilized, equating her with shamanic nat kadaw, who traffic in the occult, are sometimes possessed by spirits, and are well-known for transgressing normative expectations keyed to gender, sexuality, and myriad other domains of practice and desire. On these and other grounds, Aung San Suu Kyi was depicted as both multiply hybrid and multiply transgressive, an overdetermined threat to the nation and to state sovereignty.

Although the signs are encouraging, it is too soon to tell if the generals' recent — and highly partial_ embrace of a new era of openness will prove to be a turning 
point in Burma's political development. It is likewise premature to speculate on what processes of democratization and heightened engagement with neoliberal globalization will mean for Burma, and for dynamics of gender and sexuality in particular. If events in post-Suharto Indonesia are anything to go by, Burma's record may well be mixed, especially in the short term. Nonetheless noteworthy is that in both settings, and across Southeast Asia as a whole, ordinary women are increasingly involved in forms of popular ritual and religious activity (e.g., mass lay meditation movements, healing sects, Quranic recitation groups) that have become democratized, and that clearly facilitate their quests for heightened piety and greater agency as well as "security, self-initiative, and dignity in the face of far-reaching social change" (Hefner 2010, 1034; see also Frisk 2009, Jordt 2007, and Schober 2011; cf. Mahmood 2005).

Of broader concern is that gendered and sexual violence perpetrated by state agents and their policies, some of which are central to deeply contested processes of state formation, has been a major focus of research by anthropologists and others working in Southeast Asia in the past decade or so, even though scholars also recognize that state initiatives are sometimes aimed at protecting the bodies and well-being of an expansive range of the subjects within their jurisdictions, as distinct from coercively controlling or harming large numbers of them. Before exploring this theme in more detail, I want to draw attention to the tendency on the part of many anthropologists, sociologists, political scientists, historians, and others writing about gender, sexuality, and embodied subjectivities in Southeast Asia — and among Southeast Asians in the diaspora - to deal with the state, more specifically, the nation-state, in one of two fairly distinct, oftentimes nonoverlapping ways. The first approach involves concentrating on state-sanctioned violence, state policies (concerning labor, migration, and citizenship, for example), governance (surveillance/discipline/control), and relations with civil society and/or NGOs formed to combat illiteracy, polygyny, prostitution, sexual and gendered violence, HIV/AIDS, and the like: the "state" side of the nationstate construct. The second involves prioritizing symbols, meanings, semantics, and experiences of personhood, identity, becoming, belonging/assimilation/ cultural adjustment (e.g., to "imagined communities"), moral and ethical (as well as subcultural) language, nationhood, and desire: the "nation" side of the nation-state construct. Compare, for example, Nguyen-vo (2008) and Kwon (2006) on Vietnam; Newberry (2006) and Brenner (1998) on Java; Wieringa (2002) and Boellstorff (2005) on Indonesia generally; Parreñas (2011) and Manalansan (2003) on Filipinos in the diasporic contexts of Tokyo and the United States, respectively; and Ong (2003) and Smith-Hefner (1999) on Cambodian American communities in the San Francisco Bay Area and greater metropolitan Boston, respectively.

To some degree, this odd divide reflects the enduring tenacity of a dichotomy between Marxist-oriented “political economy” and Weberian/Geertzian-based "interpretive/symbolic/cultural" approaches in anthropology and related fields, 
notwithstanding that anthropology and kindred disciplines may be in the midst of a "post-paradigm" phase perhaps best characterized by a retreat from master narratives and grand theory (Knauft 2006). I hasten to add that the scholarly landscapes are much richer and more complicated than suggested by my simplistic formulation, which is an observation rather than a critique in any event. One reason for this is that many scholars in each camp draw heavily though variably on Antonio Gramsci (especially as refracted through Raymond Williams), Michel Foucault, and Pierre Bourdieu-as well as Judith Butler, Gayle Rubin, Lisa Rofel, Elizabeth Povinelli, Joan Scott, Sherry Ortner, and other feminists and queer theorists, many of whom are themselves theoretically eclectic-thus blurring the lines between the scholarly communities at issue and rendering efforts to draw neat lines around them a somewhat futile endeavor. A second reason has to do with the fact that many anthropologists and others working on the topics at issue here have been at the forefront of efforts to develop and/or further one or another disciplinary or transdisciplinary turn (the cultural turn, the historic turn, the poststructural/postmodern turn, the spatial/transnational turn, the affective turn, the ethical turn, etc.), most of which cross-cut the divide to which I have drawn attention. A third, related reason is burgeoning scholarly interest in citizenship, most notably cultural citizenship in diasporic contexts (see, e.g., Ong 2003; Parreñas 2011), which also cuts across the divide mentioned earlier and has proven to be one of the most productive optics through which to explore the mutually constituted entailments of race, class, and gender. As political scientist Susan Blackburn $(2004,84)$ argues in her discussion of citizenship in Indonesia, "Consideration of citizenship brings into focus the relationships between the individual, the collectivity and the state, in a way that highlights important political concepts such as identity, freedom, equality, justice, care, participation and power, all central concerns of feminist politics."

Sociologist Rhacel Parreñas further substantiates the latter argument through her compelling ethnographic study of Filipina hostesses in Tokyo's working-class nightclubs, Illicit Flirtations (2011). These scantily clad women and the transgendered phenotypic males (bakla) who endeavor to outperform them are not commonly subject to "sexual trafficking" or "sexual coercion" as these terms are typically understood (by U.S. and international legal regimes, for instance). The exploitation they experience derives instead from the euphemized violence of Filipino and Japanese state policies bearing on labor and migration; from Japan's class- and racially biased restrictions on migrant workers and the shreds and patches of citizenship to which individuals thus classified are entitled; and from unscrupulous labor brokers, entertainment managers, and (in some cases) their clients. Contrary to a good deal of hype from governments and media alike, in other words, these women are not "waiting to be rescued," though Parreñas shows that they would certainly benefit from tamped down racism, expanded citizenship, decriminalization of illegal residency, less peonage and affective labor, greater workplace flexibility, and other policies 
aimed at "harm reduction."7 This is also true of their bakla sisters (most of whom self-identify as both bakla and gay), even though a number of them told the ethnographer that, compared to the Philippines, Japan is "a bakla paradise" (21, 86). Much the same holds for Filipina maids in Hong Kong (Constable 2007), and for Indonesian women who migrate to Saudi Arabia, Malaysia, Singapore, and elsewhere in hopes of securing jobs as domestic workers (Killias 2010). Filipino, Indonesian, and other Southeast Asian men who travel to Saudi Arabia and other Middle Eastern destinations in search of meaningful wages and a better life do not necessarily fare much better, though a good deal depends on their class background and religious affiliation (Johnson 2010; Margold 1995). Gay Filipinos in the United States, by contrast, appear to have more positive views of the diasporic experience (Manalansan 2003), though most such views are not shared by their Cambodian American counterparts who self-identify as gay or in terms of one or another Khmer-language analogue (Peletz 2009, 284-89).

All things considered, it is not surprising that gendered and sexual violence brought about by state agents and their policies has been a key research priority for anthropologists and others working in Southeast Asia in the past decade or so. Consider the history of colonial-era and subsequent violence in the region, not least the violence entailed in U.S. policies toward the Philippines since 1898; our twenty-five-year war in Vietnam (1950-75); and Pol Pot's murderous regime in Cambodia (1975-79), which many scholars see as a direct outcome of U.S. military strategies in Cambodia and Indochina as a whole. On the other hand, it is striking that for the most part gendered and sexual violence in Southeast Asia was not a topic of broad scholarly concern prior to the new millennium, as evidenced by its relative absence from edited collections and state-of-the-field review essays published before that time (Atkinson and Errington 1990; Bowen 1995; Jackson and Cook 1999; Ong and Peletz 1995; Sears 1996; Steedly 1999).

Much recent work has been inspired by anthropologist Ann Stoler's Foucauldian scholarship bearing on the cultural-political logics of the highly sexualized, racialist policies promulgated by colonial agents in the Dutch East Indies and elsewhere (e.g., Stoler 1995, 2002). In many cases, however, scholars writing on Southeast Asia have opted for more empirically oriented analyses that are less theory-driven and more concerned with documenting the loves, passions, sacrifices, and losses of those on the receiving end of state policies, large numbers of whom have witnessed some of the most horrific excesses of state power and paranoia the world has ever seen. One example is psychologist Peg LeVine's (2010) volume on the traumas endured by those who lived through the horrors of the Pol Pot regime, which was responsible for the deaths (through illness, starvation, or execution) of between 1.7 and 2.1 million people, over 20 percent of Cambodia's

${ }^{7}$ In a long-awaited collection of essays, Gayle Rubin (2011) provides incisive commentary on many aspects of current debates involving "sex trafficking"; see also Roger Lancaster's compelling (2011) analysis of how sex panics figure into the discourses and practices of increasingly punitive states. 
entire population. Based on seven years of research (centered around interviews with those who survived to tell their stories) during the period of 1997-2004, LeVine explores ordinary Cambodians' lived experiences of love, dread, and ritual harm under the Khmer Rouge. The emotional, psychological, and spiritual suffering they underwent was of course due in no small measure to the cruel torture and incomprehensible human death toll and to the fact that "even the cows were starving; they couldn't even chew” (117). But the scope, force, and meaning of that toll were also heavily informed by the extreme attenuation of rites of passage conventionally associated with courtship, marriage, pregnancy, and birth, and the attendant violence done to ancestral beings and other spirits that were largely neglected during this time. Put differently, fear of Angkar (the party organization; the Khmer Rouge) was exacerbated by existential and cosmological disorientation stemming from the neglect of ritual and spirits; indeed, "despair ... [changed] to dread the longer people went without ritual access and spirit protection" (174). More generally, because "body images [were] too distorted to ever digest or to forget," people felt themselves too ugly to touch even by their own hands $(115,162)$. In addition, just as "women stopped menstruating, stopped touching silk, stopped feeling pretty, [and] stopped feeling female or sexual..., men stopped having erections and were cut off from feeling desire"; for many, even the possibility of experiencing "passion and/or love ... was virtually absent; ... [and] one could no longer imagine any future" $(33,137,176)$.

Even at the turn of the new millennium, many who survived the Khmer Rouge are "still confused and haunted by memories of human decay"; as one man explained to Levine, "I could not laugh; I was broken; [and] even today," because of fear and anxiety that the Khmer Rouge will return, "I try not to get tricked by happy times" $(161,174)$. These affective orientations pose serious dilemmas for national and international efforts to promote healing and reconciliation. Because memories of traumatic experiences are given form and meaning by the specificities of particular locales, these orientations also make clear that our understandings of how state excesses under the Khmer Rouge impacted bodies, desires, and subjectivities must draw upon the memories and experiences of Cambodians in the diaspora (Ong 2003; Smith-Hefner 1999). Many diasporic Cambodians are understandably less concerned with the return of the Khmer Rouge-and thus freer to recollect the sights, sounds, smells, and tastes of their past - than their compatriots back home. Analogous arguments might be made with reference to Vietnamese and Laotians who reside in the diaspora as distinct from their countries of origin (Aguilar-San Juan 2009; Kwon 2006).

\section{Women's Activism and Sexual Politics}

Recent ethnographies on Cambodia and its diaspora are usefully read alongside historian Vina Lanzona’s (2009) monograph on women, gender, and sexuality 
in the Philippines' Hukbalahap (Huk) Rebellion (1942-56), which also makes extensive use of oral history. This meticulously researched volume provides more upbeat perspectives on the agency of women (and men) vis-à-vis the state than most of the scholarship considered thus far (though, perhaps understandably, not a particularly positive view of the state). But it also elucidates the pronounced constraints on women's agency-constraints emanating not only from Filipino feudalism, "traditional" kinship/gender arrangements, the Catholic Church, U.S. colonialism, and the post-war Republic of the Philippines, but also from male comrades within the communist-oriented revolutionary movement itself. The 1,000-2,000 women actively involved in this peasant-/ community-based movement, dubbed "Huk Amazons" by the media, comprised perhaps 10 percent of its overall personnel, and "were followed with intense curiosity and scrutiny in the press, ... women warriors elicit[ing] awe and admiration, as well as fear and hostility" (130). Among the reasons for this is that as the movement progressed, some consistently well-coiffed and conventionally beautiful women moved from being "subsidiaries" or "appendices" to key players in its upper echelons. The clear message was that women could endeavor to influence state policy and contribute to the nation not just through their devotion to "a single home and ... a single man" (68), and could otherwise combine elements of femininity and masculinity in shockingly novel ways, sometimes with quite deadly effect.

Unfortunately, while the leaders of the Huk movement "rejected the Catholicism, monogamy, and sexual conventionality of mainstream Philippine society" (185), they still operated with deep-seated double standards. Some of them involved pressuring Huk women to form marital and sexual partnerships with male comrades (as the latter's "forest wives"), even when these men had wives outside the forest. In short, extramarital relationships by men, but not women, were accorded legitimacy by the party, and on many critically important issues bearing on kinship, gender, and sexuality, women's opinions were largely disregarded. Revelations about these arrangements led to media accounts claiming that "communism apparently leads to fornication in the forest, promiscuity in the party," and that "with no moral or religious principles to keep them away from evil, the Huks fell headlong into the precipitous abyss of sex and grave moral disorder" (214).

The more encompassing nexus of issues in all of this-at once theoretical, methodological, and historiographical—is the pronounced degree to which "gender 'mediates' the activist experience" (9). These issues are also central to path-breaking work on women in revolutionary China during the 1950s and 1960s (Hershatter 2011), and to a good deal of feminist scholarship on women's movements in Asian contexts as diverse as Japan, Korea, Singapore, Pakistan, and India (Roces and Edwards 2010).

One of the best documented (and most chilling) cases of women's political agency and its variable consequences is anthropologist Saskia Wieringa's (2002) 
account of the Indonesian Women's Movement (Gerakan Wanita Indonesia), known by the acronym Gerwani. (Another is Siapno 2002.) Through detailed analysis of archival sources and interviews with former members of Gerwani (among others), Wieringa traces the intertwining of nationalist, socialist, and feminist struggles and state discourses in the archipelago from the early 1900s through the October 1965 coup, which saw the end of the Sukarno era, resulted in the deaths of up to one million people, and paved the way for Suharto's New Order. Partly because they have been largely ignored by “'male-stream' historiographies" (52), Wieringa is committed to unraveling the sexual and gendered dimensions of the "events of October 1965," as they are sometimes euphemistically referred to. Especially germane is that members of Gerwani are said to have castrated or otherwise sexually tortured six high-ranking generals with small knives and razor blades, to have engaged in promiscuous, orgiastic "mad dancing" prior to gouging out the generals' eyes, and then to have dumped their mangled bodies into a well. One of the subtexts of this widely circulated and (even today) widely accepted narrative-which is contradicted by hard evidence (303) — is that, as it evolved, Gerwani embraced many of the platforms of the Indonesian Communist Party (PKI), eventually becoming the women's wing of the PKI. The PKI and communists as a whole were tarred by many critics occupying or seeking to ensconce themselves in the corridors of power as advocating prostitution, lesbianism, and other kinds of "sexual promiscuity" and moral depravity that threatened the basic building blocks of Indonesian society (e.g., male-headed heteronormative families). This notwithstanding that, as Wieringa shows, Gerwani long espoused relatively conservative views on most aspects of kinship, marriage, gender, and sexuality. More directly relevant is that allegations concerning the sexual and gendered dimensions of the coup led to the imprisonment, torture, rape, and murder of many members of Gerwani and also became central features of the New Order origin story. As such, they provided a mythic charter for conservative policies toward women, grounded in (usually) implicit ideologies of women's "nature" and destiny (kodrat wanita), that were (and still are) advanced throughout the archipelago by extremely influential organizations and movements such as the PKK (Pembinaan Kesejahteraan Keluarga-Support for the Prosperous Family, or Family Welfare Movement) and Dharma Wanita (Duty of Women, an association of civil servants' wives) (Blackburn 2004; Newberry 2006).

\section{Moral Policing and Graduated Pluralism}

One may be tempted to conclude, as many scholars have, that the New Order account of its birth "depicts sexual violence [by women] as the ultimate form of treachery" (Strassler 2004, 702). As a friendly amendment to this interpretation, I would suggest viewing the New Order tale of its origins in comparative-historical 
terms, and asking whether the ultimate form of treachery in question is in fact women's sexual violence per se as distinct from something more generalized or variable: sexual aberration or gender deviance as defined by one or another normalizing metric. The New Order origin story resonates in important ways with the Burmese junta's long-standing depictions of Aung San Suu Kyi's alleged sexual and reproductive transgressions; with American and Filipino officials' characterizations of Huk "fornication," "promiscuity," and "moral depravity" involving men and women alike; and with the Malaysian state's allegations of sodomy on the part of former deputy prime minister and current opposition leader Anwar Ibrahim (which resulted in the widely reverberating "Anwar crisis"). As Mark Twain put it, history does not repeat itself, but it does rhyme.

The larger themes are that sexual and gender differences are commonly portrayed as "deep categorical treacheries" in Arjun Appadurai's $(1996,154)$ terminology, and that agents of governmentality, aided by an always eager media, frequently depict deep categorical treacheries as broadly ramifying violence. These kinds of cultural linkages are certainly not new, as evidenced by the twinned themes of incest and cannibalism that appear repeatedly in the origin myths collected by anthropologists and others over the centuries. In their current, mass-mediated incarnations, however, conceptual linkages of this sort can easily fuel dangerous (socially divisive) moral panics, most notably when economic and cultural-political circumstances are conducive to the "punitive turns" taken by many states in Southeast Asia and the West in recent decades (Lancaster 2011; Peletz 2009; Tan 2012). In such cases, they are readily harnessed to the cause of legitimizing the febrile moral policing we see in various parts of Southeast Asia. I am thinking most immediately of Singapore and Malaysia. But also of Aceh, West Java, and other regions of Indonesia that have witnessed the introduction in the post-Suharto era of syariah-inflected kanun and bylaws. These laws are ostensibly aimed at curbing corruption, prostitution, gambling, and the consumption of alcohol. But they tend to be used by religious police and vigilante groups to discipline and punish women for styles of dress and comportment that are deemed seductive, pornographic, or otherwise inappropriate according to ascendant views of classical Islam.

Dynamics leading to democratization and decentralization in Indonesia have obviously entailed a good deal of instability and violence, and a disproportionate amount of suffering for women (but see Blackburn 2004, 220-22 passim; SmithHefner 2007; Tsing 2005). The infamous gang rape and murder of Chinese Indonesian women in mid-May 1998, during the rioting that brought an end to Suharto's regime, is relevant here and may become a topic-locale icon in the literature and in the public's eyes in some of the same general ways as gendered and sexual violence following the post-war partition of India. Karen Strassler (2004) has shown how provocateurs, aided by high-level state authorities, appear to have been centrally involved, and that the "mobilization of journalistic, documentary 
photography against state power ... played an integral role" in the movement for reform (701), much like what we have seen in recent years in the context of the "Arab Spring." The downside is that "exposed women's bodies [became] the objects of prurient sexual fantasy and consumption," and that many female survivors who sought justice had to display "their bodies and their suffering" to "the threatening scrutiny of a state hostile to their claims," and thus "feared being 'raped a second time" (701). Compounding the difficulties and chaos was the circulation via the Internet and other media of fabricated photos and rumors that greatly exaggerated the horrendous violence, trashed Indonesia's image abroad, and became a rallying point for the world's diasporic Chinese, whose material and symbolic connections with Chinese Indonesians clearly transformed the scope and force of the crisis both in Indonesia and in the global arena (cf. Ong 2003, 53-72). Regrettably, the strategic use of rape as a technique of terror - in Aceh, East Timor, and Irian Jaya, to cite other Indonesian examples, and in post-partition India as well as Bangladesh, Bosnia, Rwanda, Darfur, and numerous other locales in Africa and elsewhere-is globally widespread and increasingly so.

This brings me to Malaysia and Southeast Asia generally, and to rather different sets of issues. A few decades ago, Malaysia was arguably the locus classicus of ethnographic studies of resistance, due largely to Scott's Weapons of the Weak (1985) and Ong's Spirits of Resistance and Capitalist Discipline (1987). At present, however, owing to ominous trends in governmentality and statesponsored Islamization that have been documented by Maila Stivens (2002), Norani Othman et al. (2008), Julian Lee (2010, 2011), Tan Beng Hui (2012), and others, it is better known as a site of constricted pluralism and moral policing.

To help make sense of the latter phenomena in Malaysia and Southeast Asia more broadly, I developed the concept of graduated pluralism. As discussed elsewhere (Peletz 2009), the term "graduated pluralism" draws attention to the differential distribution, throughout societies, polities, transnational/diasporic spaces, and historical periods, of certain kinds of sentiments, dispositions, and institutionalized arrangements conducive to or inhibiting pluralism, many of which are keyed to systems of stratified reproduction defined as encompassing systems of power relations that encourage certain groups' nurturance and reproduction, while discouraging or precluding those of others (cf. Colen 1995; Foucault 1978). I developed this concept partly because it makes little empirical or theoretical sense to speak of pluralism — or of tolerance, legitimacy, justice, sovereignty, or power - in the abstract. Regimes of pluralism, like regimes of justice, sovereignty, power, etc., are internally differentiated and domain specific, just as they are deeply grounded in the specificities of globally inflected local histories. The concept of graduated pluralism encourages recognition of these facts, helping us to appreciate as well that pluralistic sentiments and dispositions with respect to gender and/or sexual diversity may or may not help constitute 
pluralistic sentiments and dispositions bearing on diversity defined in terms of race, ethnicity, and/or religion - and vice versa. In Southeast Asia, pluralism with regard to gender and sexuality has long been rather robust, and typically far more expansive than its counterparts in the West. But it has always been relative. Various kinds of "close mating" (construed as incest) and extramarital unions, for instance, have always been beyond the pale, as for the most part have same-sex erotics involving homogender as distinct from heterogender relations. It is also clear that male-bodied persons, however gendered, have usually been allowed far more bodily "play" than their female-bodied counterparts.

The logic underlying many of these distinctions (e.g., heterogender versus homogender) is imbricated in various discursive modes, including religiously grounded mythologies and cosmologies, though I am not able to address these matters in any detail here. The point is nonetheless worth emphasizing inasmuch as it helps distinguish the notion of graduated pluralism from others to which it bears a loose family resemblance, such as Ong's more state-centric idea of graduated sovereignty. The latter concept was also developed primarily in relation to Southeast Asian material, and, as noted earlier, is central to studies by Wilson and Nguyen-vo on Bangkok and Ho Chi Minh City, respectively. It refers to processes in which "the state makes different kinds of biopolitical investments [both] in different subject populations, privileging one gender over the other," for example, and "in certain kinds of human skills, talents, and ethnicities," along with its willingness, even as it "maintains control over its territory, ... to let corporate entities set the terms for constituting and regulating some domains" (Ong 1999, 217). Ong deploys the concept of graduated sovereignty primarily to designate post-Fordist dynamics that have arisen with neoliberal globalization, suggesting that hype-rational states and transnational corporations driven by wills to power and profit and other largely utilitarian agendas are invariably the key players in driving these dynamics. The notion of graduated pluralism, by contrast, accords more significance to the cosmological underpinnings of state apparatuses and the conceptual schema informing the subjectivities and practice of agents of governmentality and their proxies and charges, and the ways these cosmologies and conceptual schema are dialectically related to myth, ritual, and various domestic and social structural arrangements. It remains to add that the two concepts, like the literatures to which they are keyed, are by no means mutually exclusive, and that bringing them more directly into conversation with one another will further illuminate the myriad ways in which states and bodies are implicated in dynamics of power, prestige, legitimacy, and difference both in Southeast Asia and its diaspora and beyond. More generally, my argument is that we have much to learn from exegeses of graduated pluralism and its structuring in different world areas that take seriously both regional specificity and historical dynamics of the longue durée, and that such approaches are conducive to transcending many of the dichotomies sketched out earlier in this essay. 


\section{Conclusion}

I bring this essay to a close by drawing attention to three sets of issues. The first has to do with the conspicuous absence in the anthropological and other literature on gender and sexuality in Southeast Asia-indeed, the deafening silence -with respect to empirical and theoretical perspectives on normative masculinities (which should not be confused with masculine or masculinist perspectives), especially those that prevail among ordinary folks outside arenas of colonial rule, warfare, militarization, and ethno-nationalistic, religious, or racial strife. (See in this connection Kam Louie's [2012] call to "free the study of masculinity from the study of empire.") This domain of gender and sexuality continues to suffer from the "taken-for-granted syndrome," as I observed some time ago (Peletz 1995, 78-79, 1996, 4-7 passim; but see McCoy 1999, Reyes 2008, and most recently Ford and Lyons 2012, which constitute important but partial exceptions that prove the rule). ${ }^{8}$ By contrast, scholarship on communities of phenotypic males who self-identify as transgendered (kathoey, waria, bakla, bantut, etc.), gay, or queer, and/or are performatively feminized, is both robust and theoretically sophisticated, as is the literature on heteronormative women, female-bodied masculinities (e.g., toms), and (to a lesser extent) feminine females in erotic relationships with masculinized females. If only because notions of gender and sexuality (such as distinctions between "good sex" and "bad sex") are inherently relational, this lacunae should be addressed in future research on Southeast Asia.

The second issue, largely glossed over in this essay, is that states are of course capable of all sorts of initiatives that are positive (or at least potentially so). Many such initiatives are alive and well in various parts of Southeast Asia and have been for decades. They include mass immunizations and other public health campaigns that reduce infant mortality, improve hygiene and nutrition, and help prevent the ravages of water-borne and other diseases (such as HIV/AIDS) in men, women, and children alike; irrigation and other water-control projects aimed at enhancing agricultural yields and lessening the likelihood of devastating floods; programs of economic development geared toward raising wages and living standards; educational and legislative reforms with the capacity to greatly increase rates of literacy, participation in electoral processes, and overall equality between women and men; and defensive and/or peace-keeping measures that depoliticize divisive religious issues, constrain uncivil elements of civil society, and protect national boundaries from foreign incursions and the destruction and havoc they might bring.

The third, related issue, which is more obvious from the thrust of this essay, is that the positive dimensions and outcomes of state practices (positive state effects) do not figure prominently in the scholarship on gender, sexuality, and

\footnotetext{
${ }^{8}$ This shortcoming is far less pronounced in the literature concerning other world areas (see, e.g., Guttman 1996; Lancaster 1992; Louie 2002; Louie and Low 2003; Ouzgane 2006).
} 
the state in Southeast Asia, at least not in the literature produced by anthropologists, historians, sociologists, political scientists, feminists, and queer theorists. ${ }^{9}$ Had I focused instead on scholarship in the fields of epidemiology, public health, economic development, environmental studies, and political ecology, the overall picture might be rather different; then again, see Hall et al. (2011), Peluso (1992), and Pisani (2008).

An adequate explanation of this pattern would require an altogether separate essay. Suffice it to say that, as far as many scholars are concerned, the era of late capitalism has given way since the 1970 s or so to a period characterized by neoliberalism or neoliberal globalization (though the neoliberal gloss, like that of globalization, did not begin to take hold until the late 1990s), and that states, market forces, and institutions of governance in the latter period are generally viewed in far more destructive and negative (fundamentally "anti-human") terms than their immediate predecessors (Ortner 2011). These views are not due, as some might suggest, to the anti-Enlightenment stances and other dark visions of influential scholars such as Foucault, who did in any event draw heavily on the late nineteenth- and early twentieth-century writings (some of them quite gloomy) of Nietzsche and Weber, which obviously predate neoliberalism. Rather, the relevant issue is that in the past few decades, neoliberal states, regimes of governance, and the cultural-political dynamics that help sustain them across broad stretches of Asia and the West have been experienced by large numbers of people as increasingly intrusive and punitive, ${ }^{10}$ thus encouraging scholarly engagement with Foucault's prescient arguments about surveillance, discipline, and control, and sometimes eclipsing scholarly (and public) appreciation of the liberatory and other positive initiatives that states are capable of undertaking.

\section{Acknowledgments}

I presented an early version of this essay at the panel on Sexuality and the State in Asia that was convened at the Annual Conference of the Association for Asian Studies (AAS) in Toronto in March 2012. Thanks to Jennifer Munger, Jeffrey Wasserstrom, and others at the AAS for coming up with the idea of the panel and for including me in it, and to fellow panelists and members of the audience for stimulating discussion. I am grateful to Ikmal Adian Mohd Adil for research and editorial assistance and would also like to thank Robert Hefner, Mark Johnson, and Rachel Leow for kindly reading the penultimate draft of the essay on short notice and providing helpful

\footnotetext{
${ }^{9}$ Susan Blackburn's Women and the State in Modern Indonesia (2004) constitutes an important exception to this generalization insofar as Blackburn shows how various state measures over the course of the twentieth century and the early years of the new millennium have served to empower women even while others have had quite the opposite effect.

${ }^{10}$ Scholars debate whether in the United States, for instance, "the punitive turn prepared the way for the neoliberal turn, ... [or] vice versa" (the former appears more likely); but there is little question as to the "coupling of punitive governance with neoliberal economic policies" both in the United States and far beyond (Lancaster 2011, 222, 245).
} 
comments. Due to space limitations, I am unable to engage a good deal of the relevant literature (much of which is cited in the bibliographies of Peletz [2007, 2009]) and many important issues; for the same reasons, I have limited the list of references to Englishlanguage sources. Some of the material presented here is adapted from previous publications (Peletz 2009, 2011).

\section{List of References}

Abrams, Philip. 1988. "Notes on the Difficulty of Studying the State." Journal of Historical Sociology 1(1):58-89.

Agullar-San Juan, Karin. 2009. Little Saigons: Staying Vietnamese in America. Minneapolis: University of Minnesota Press.

Andaya, Barbara. 2006. The Flaming Womb: Repositioning Women in Early Modern Southeast Asia. Honolulu: University of Hawai'i Press.

Appadurai, Arjun. 1996. Modernity at Large: Cultural Dimensions of Globalization. Minneapolis: University of Minnesota Press.

Aretxaga, Begona. 2003. "Maddening States." Annual Review of Anthropology 32:393-410.

Atrinson, Jane, and Shelly Errington, eds. 1990. Power and Difference: Gender in Island Southeast Asia. Stanford, Calif.: Stanford University Press.

Вiсh, Рнам Van. 1999. The Vietnamese Family in Change: The Case of the Red River Delta. Richmond, Surrey, England: Curzon.

Blackburn, Susan. 2004. Women and the State in Modern Indonesia. Cambridge: Cambridge University Press.

Blackwood, Evelyn. 2010. Falling Into the Lesbi World: Desire and Difference in Indonesia. Honolulu: University of Hawai'i Press.

Blackwood, Evelyn, and Saskia Wieringa, eds. 1999. Female Desires: Same-Sex Relations and Transgender Practices Across Cultures. New York: Columbia University Press.

Boellstorff, Tom. 2005. The Gay Archipelago: Sexuality and Nation in Indonesia. Princeton, N.J.: Princeton University Press.

- 2007. Coincidence of Desires: Anthropology, Queer Studies, Indonesia. Durham, N.C.: Duke University Press.

Bowen, John. 1995. "The Forms Culture Takes: A State-of-the-Field Essay on the Anthropology of Southeast Asia." Journal of Asian Studies 54(4):1047-78.

Brenner, Suzanne. 1998. The Domestication of Desire: Women, Wealth, and Modernity in Java. Princeton, N.J.: Princeton University Press.

Butalia, Urvashi. 2000. The Other Side of Silence: Voices from the Partition of India. Durham, N.C.: Duke University Press.

Colen, Shellee. 1995. “Like a Mother to Them”: Stratified Reproduction and West Indian Childcare Workers and Employers in New York.” In Conceiving the New World Order: The Global Politics of Reproduction, ed. Faye Ginsburg and Rayna Rapp, 78-102. Berkeley: University of California Press.

Comaroff, Jean, and John Comaroff, eds. 2000. Millennial Capitalism and the Culture of Neoliberalism. Special issue of Public Culture 12(2):291-564.

Constable, Nicole. 2007. Maid to Order in Hong Kong: Stories of Filipina Workers, 2nd ed. Ithaca, N.Y.: Cornell University Press. 
Croll, Elisabeth. 2000. Endangered Daughters: Discrimination and Development in Asia. New York: Routledge.

Das, VInA. 1995. "National Honor and Practical Kinship: Unwanted Women and Children." In Conceiving the New World Order: The Global Politics of Reproduction, ed. Faye Ginsburg and Rayna Rapp, 212-33. Berkeley: University of California Press.

Davies, Sharyn G. 2010. Gender Diversity in Indonesia: Sexuality, Islam, and Queer Selves. New York: Routledge.

Day, Tony. 2002. Fluid Iron: State Formation in Southeast Asia. Honolulu: University of Hawai'i Press.

Ford, Michelle, and Lenore Lyons, eds. 2012. Men and Masculinities in Southeast Asia. New York: Routledge.

Foucault, Michel. 1978. The History of Sexuality, Vol. I: An Introduction. New York: Vintage.

Frisk, Sylva. 2009. Submitting to God: Women and Islam in Urban Malaysia. Copenhagen: Nordic Institute of Asian Studies.

Guttman, Matthew. 1996. The Meanings of Macho: Being a Man in Mexico City. Berkeley: University of California Press.

Hall, Derek, Philip, Hirsch, and Tanya M. Li. 2011. Powers of Exclusion: Land Dilemmas in Southeast Asia. Honolulu: University of Hawai i Press.

Harvey, David. 2005. A Brief History of Neoliberalism. Oxford: Oxford University Press.

Hefner, Robert W. 2010. "Religious Resurgence in Contemporary Asia: Southeast Asian Perspectives on Capitalism, the State, and the New Piety." Journal of Asian Studies 69(4):1031-47.

Hershatter, Gail. 2011. The Gender of Memory: Rural Women and China's Collective Past. Berkeley: University of California Press.

IPAS. 2004. "Vietnam: Reproductive Health and Abortion Statistics." http://ideas.ipas.org/ cgi-bin/ideas.ipas.org/ideas.cgi?request=Repro\&COUNTRY=Vietnam (accessed February 27, 2011).

Jackson, Peter A. 1997. "Kathoey $><$ Gay $><$ Man: The Historical Emergence of Gay Male Masculinity in Thailand." In Sites of Desire, Economies of Pleasure: Sexualities in Asia and the Pacific, ed. Lenore Manderson and Margaret Jolly, 166-90. Chicago: University of Chicago Press.

Jackson, Peter A., and Nerida M. Cook, eds. 1999. Gender and Sexualities in Modern Thailand. Chiang Mai: Silkworm Press.

Johnson, MARK. 1997. Beauty and Power: Transgendering and Cultural Transformation in the Southern Philippines. London: Berg.

—. 2010. "Diasporic Dreams, Middle-Class Moralities, and Migrant Domestic Workers Among Muslim Filipinos in Saudi Arabia." The Asia Pacific Journal of Anthropology 11(3/4):428-48.

JoRdt, INGRID. 2007. Burma's Mass Lay Meditation Movement: Buddhism and the Cultural Construction of Power. Copenhagen: Nordic Institute of Asian Studies.

Killias, Olivia. 2010. “Illegal' Migration as Resistance: Legality, Morality, and Coercion in Indonesian Domestic Worker Migration to Malaysia." Asian Journal of Social Science 38:897-914.

Knauft, Bruce. 2006. "Anthropology in the Middle." Anthropological Theory 6 (4):407-30.

Kwon, Heonik. 2006. After the Massacre: Commemoration and Consolation in Ha My and My Lai. Berkeley: University of California Press. 
Lancaster, Roger N. 1992. Life Is Hard: Machismo, Danger, and the Intimacy of Power in Nicaragua. Berkeley: University of California Press.

- 2011. Sex Panic and the Punitive State. Berkeley: University of California Press.

Lanzona, Vina. 2009. Amazons of the Huk Rebellion: Gender, Sex, and Revolution in the Philippines. Madison: University of Wisconsin Press.

LeE, Julian C. H. 2010. Islamization and Activism in Malaysia. Singapore: Institute of Southeast Asian Studies.

- 2011. Policing Sexuality: Sex, Society, and the State. London: Zed Books.

LeVine, Peg. 2010. Love and Dread in Cambodia: Weddings, Births, and Ritual Harm Under the Khmer Rouge. Singapore: National University of Singapore Press.

Loos, Tamara. 2005. "Sex in the Inner City: The Fidelity Between Sex and Politics in Siam.” Journal of Asian Studies 64(4):881-909.

. 2009. "Transnational Histories of Sexualities in Asia." American Historical Review 114(5):1309-24.

Louie, Kam. 2002. Theorising Chinese Masculinity: Society and Gender in China. Cambridge: Cambridge University Press.

— 2012. "Changes in Gender Ideals in China as a Consequence of East Asian Circulations of Popular Culture through the Internet." Paper presented at Annual Conference of the Association for Asian Studies, Toronto, March 15-18.

Louie, Kam, and Morris Low, eds. 2003. Asian Masculinities: The Meaning and Practice of Manhood in China and Japan. London: RoutledgeCurzon.

Manmood, SAвa. 2005. Politics of Piety: The Islamic Revival and the Feminist Subject. Princeton, N.J.: Princeton University Press.

Manalansan, Martin. 2003. Global Divas: Filipino Gay Men in the Diaspora. Durham, N.C.: Duke University Press.

Margold, Jane. 1995. "Narratives of Masculinity and Transnational Migration: Filipino Workers in the Middle East." In Bewitching Women, Pious Men: Gender and Body Politics in Southeast Asia, ed. Aihwa Ong and Michael G. Peletz, 274-98. Berkeley: University of California Press.

McCoy, Alfred. 1999. Closer Than Brothers: Manhood at the Philippine Military Academy. New Haven, Conn.: Yale University Press.

Mitchell, Tiмотнy. 1991. "The Limits of the State: Beyond Statist Approaches and Their Critics." American Political Science Review 85(1):77-96.

Morris, Rosalind. 1994. "Three Sexes and Four Sexualities: Redressing the Discourses on Gender and Sexuality in Contemporary Thailand.” positions 2(1):15-43.

Newberry, Jan. 2006. Back Door Java: State Formation and the Domestic in Working Class Java. Peterborough, Ontario: Broadview Press.

Nguyen-vo, Thu-huong. 2008. The Ironies of Freedom: Sex, Culture, and Neoliberal Governance in Vietnam. Seattle: University of Washington Press.

Norani Othman, Mavis Puthucheary, and Clive Kessler. 2008. Sharing the Nation: Faith, Difference, Power, and the State 50 Years After Merdeka. Petaling Jaya: Strategic Information and Research Development Centre.

Оетомo, Dede. 1996. "Gender and Sexual Orientation in Indonesia." In Fantasizing the Feminine in Indonesia, ed. Laurie Sears, 259-69. Durham, N.C.: Duke University Press.

Ong, Ainwa. 1987. Spirits of Resistance and Capitalist Discipline: Factory Women in Malaysia. Albany: State University of New York Press.

—. 1999. Flexible Citizenship: The Cultural Logics of Transnationality. Durham, N.C.: Duke University Press. 
2003. Buddha is Hiding: Refugees, Citizenship, the New America. Berkeley: University of California Press.

2006. Neoliberalism as Exception: Mutations in Citizenship and Sovereignty. Durham, N.C.: Duke University Press.

Ong, Ainwa, and Michael G. Peletz, eds. 1995. Bewitching Women, Pious Men: Gender and Body Politics in Southeast Asia. Berkeley: University of California Press.

Ortner, Sherry. 2011. “On Neoliberalism.” Anthropology of This Century, Vol. 1. http:// aotcpress.com/articles/neoliberalism/ (accessed May 15, 2011).

Ouzgane, Lahouacine, ed. 2006. Islamic Masculinities. New York: Zed.

Pandey, Gyanendra. 2006. Routine Violence: Nations, Fragments, Histories. Stanford, Calif.: Stanford University Press.

Parreñas, Rhacel S. 2011. Illicit Flirtations: Labor, Migration, and Sex Trafficking in Tokyo. Stanford, Calif.: Stanford University Press.

Peletz, Michael G. 1995. "Neither Reasonable nor Responsible: Contrasting Representations of Masculinity in a Malay Society." In Bewitching Women, Pious Men: Gender and Body Politics in Southeast Asia, ed. Aihwa Ong and Michael G. Peletz, 76-123. Berkeley: University of California Press.

- 1996. Reason and Passion: Representations of Gender in a Malay Society. Berkeley: University of California Press.

- 2007. Gender, Sexuality, and Body Politics in Modern Asia. Ann Arbor, Mich.: Association for Asian Studies.

—. 2009. Gender Pluralism: Southeast Asia Since Early Modern Times. New York: Routledge.

- 2011. "Gender Pluralism: Muslim Southeast Asia Since Early Modern Times." Social Research: An International Quarterly 78(2):659-86.

Peluso, Nancy L. 1992. Rich Forests, Poor People: Resource Control and Resistance in Java. Berkeley: University of California Press.

Pisani, Elizabeth. 2008. The Wisdom of Whores: Bureaucrats, Brothels, and the Business of AIDS. New York: Norton.

Reyes, Raquel A. G. 2008. Love, Passion, and Patriotism: Sexuality and the Philippine Propaganda Movement, 1882-1892. Singapore: National University of Singapore Press in association with University of Washington Press.

Roces, Mina, and Louise Edwards, eds. 2010. Women's Movements in Asia: Feminisms and Transnational Activism. London: Routledge.

Rofel, Lisa. 2007. Desiring China: Experiments in Neoliberalism, Sexuality, and Public Culture. Durham, N.C.: Duke University Press.

Rubin, GaYle S. 1984. "Thinking Sex: Notes for a Radical Theory of the Politics of Sexuality.” In Pleasure and Danger: Exploring Female Sexuality, ed. Carole Vance, 267319. New York: Routledge and Kegan Paul.

- 2011. Deviations: A Gayle Rubin Reader. Durham, N.C.: Duke University Press.

Schober, Juliane. 2011. Modern Buddhist Conjunctures in Myanmar: Cultural Narratives, Colonial Legacies, and Civil Society. Honolulu: University of Hawai i Press.

Scott, James C. 1985. Weapons of the Weak: Everyday Forms of Peasant Resistance. New Haven, Conn.: Yale University Press.

2009. The Art of Not Being Governed: An Anarchist History of Upland Southeast Asia. New Haven, Conn.: Yale University Press.

Sears, Laurie, ed. 1996. Fantasizing the Feminine in Indonesia. Durham, N.C.: Duke University Press.

Siapno, Jacqueline. 2002. Gender, Islam, Nationalism and the State in Aceh: The Paradox of Power, Cooptation and Resistance. London: RoutledgeCurzon. 
Sinnott, Megan. 2004. Toms and Dees: Transgender Identity and Female Same-Sex Relationships in Thailand. Honolulu: University of Hawai'i Press.

Skidmore, Monique. 2004. Karaoke Fascism: Burma and the Politics of Fear. Philadelphia: University of Pennsylvania Press.

Smith-Hefner, Nancy J. 1999. Khmer American: Moral Education and Identity in a Diasporic Community. Berkeley: University of California Press.

—. 2007. "Javanese Women and the Veil in Post-Soeharto Indonesia." Journal of Asian Studies 66(2):389-420.

Steedly, Mary. 1999. "The State of Culture Theory in the Anthropology of Southeast Asia." Annual Review of Anthropology 28:431-54.

Stivens, Maila. 2002. "The Hope of the Nation: Moral Panics and the Construction of Teenagerhood in Contemporary Malaysia." In Coming of Age in South and Southeast Asia: Youth, Courtship, and Sexuality, ed. Lenore Manderson and Pranee Laimputtong, 186-206. Richmond, Surrey, England: Curzon.

Stoler, Ann. 1995. Race and the Education of Desire: Foucault's History of Sexuality and the Colonial Order of Things. Durham, N.C.: Duke University Press.

- 2002. Carnal Knowledge and Imperial Power: Race and the Intimate in Colonial Rule. Berkeley: University of California Press.

Strassler, Karen. 2004. "Gendered Visibilities and the Dream of Transparency: The Chinese-Indonesian Rape Debate in Post-Suharto Indonesia." Gender and History 16(3):689-725.

Tan Beng Hui. 2012. "Sexuality, Islam and Politics in Malaysia: A Study on the Shifting Strategies of Regulation.” PhD diss., National University of Singapore.

Tsing, Anna. 2005. Friction: An Ethnography of Global Connection. Princeton, N.J.: Princeton University Press.

Wieringa, Saskia. 1999. "Desiring Bodies or Defiant Cultures: Butch-Femme Lesbians in Jakarta and Lima." In Female Desires: Same-Sex Relations and Transgender Practices Across Cultures, ed. Evelyn, Blackwood and Saskia, Wieringa, 206-31. New York: Columbia University Press.

—. 2002. Sexual Politics in Indonesia. New York: Palgrave Macmillan.

— . 2010. "Gender Variance in Asia: Discursive Contestations and Legal Implications." Gender, Technology, and Development 14(2):143-72.

Wieringa, Saskia, Evelyn Blackwood, and AbHa Bhaiya, eds. 2007. Women's Sexualities and Masculinities in a Globalizing Asia. New York: Palgrave Macmillan.

Wilson, Ara. 2004. The Intimate Economies of Bangkok: Tomboys, Tycoons, and Avon Ladies in the Global City. Berkeley: University of California Press. 